\title{
Regulation of Insulin-like Growth Factor-I and its Receptor in Rat Aorta after Balloon Denudation

\author{
Evidence for Local Bioactivity
}

Mehran J. Khorsandi, James A. Fagin, Daniel Giannella-Neto, James S. Forrester, and Bojan Cercek

Division of Cardiology, Cedars-Sinai Medical Center, Los Angeles, California 90048-1896

\begin{abstract}
Local production of growth factors may play a major role in vascular repair after injury. We examined the regulation of insulin-like growth factor-I (IGF-I) and its specific membrane receptor in balloon-denuded rat aorta. Aortic IGF-I mRNA and radioimmunoassayable IGF-I content increased severalfold after balloon denudation with a peak at $7 \mathrm{~d}$ after injury. This coincided with a reciprocal $25 \%$ decrease in IGF-I receptor mRNA content and a $40 \%$ decrease in total ${ }^{125}$ I-IGF-I binding. Scatchard analysis indicated a single class of binding sites, with a decrease in receptor number at $7 \mathrm{~d}$ compared to control and no change in affinity. By in situ hybridization the predominant site of IGF-I expression in the normal and the denuded vessel wall was the medial smooth muscle cell. After denudation there was a relative decrease in IGF-I receptor $\mathrm{mRNA}$ in the medial cells as compared to the neointima, suggesting that the site of IGF-I action was predominantly in the medial layer. These data suggest that local expression and action of IGF-I are significant in the promotion of smooth muscle cell proliferation after arterial injury. (J. Clin. Invest. 1992. 90:1926-1931.) Key words: neointimal proliferation - gene expression • vascular smooth muscle cells
\end{abstract}

\section{Introduction}

Vascular smooth muscle cell (SMC) ${ }^{1}$ proliferation is the cardinal feature of arterial wall response to injury (1). Although the signaling events leading to SMC proliferation have not been clearly defined, platelet-derived growth factor (PDGF) released by adhering platelets has been implicated as a potential initial stimulus (2). Recently, it has been shown that PDGF is also produced by vascular SMC within the vessel wall after balloon denudation (3), suggesting that autocrine or paracrine production of growth factors may be important in vascular repair. Insulin-like growth factor-I (IGF-I), a ubiquitously expressed polypeptide $\left(M_{\mathrm{r}} 7,649\right)$ with high degree of structural homology with proinsulin, also stimulates a number of growthassociated processes in various tissues (4). Support for the role

1. Abbreviations used in this paper: IGF-I, insulin-like growth factor-I; PDGF, platelet-derived growth factor; SMC, smooth muscle cell.

Address correspondence to Bojan Cercek, Division of Cardiology, Room 5314, Cedars-Sinai Medical Center, P. O. Box 48750, Los Angeles, CA 90048-0750.

Received for publication 15 August 1991 and in revised form 13 May 1992.

J. Clin. Invest.

(C) The American Society for Clinical Investigation, Inc. $0021-9738 / 92 / 11 / 1926 / 06 \$ 2.00$

Volume 90, November 1992, 1926-1931 of IGF-I in the process of SMC proliferation comes from in vitro studies demonstrating that in addition to PDGF, aortic SMC require IGF-I to progress fully through the cell cycle (5). This is compatible with a model of cell cycle progression in mesenchymal cells in which growth factors act at discrete stages in the process of cell division (6). PDGF regulates the initial event in the mitogenic response by rendering the $G_{0}$ arrested cells competent to replicate their DNA and divide. However, the cells will not complete the process in the absence of additional factors, such as epidermal growth factor or IGF-I, which regulate progression through $G_{1}$ to the $S$ phase of the cell cycle. This mechanism may also operate in vivo. We found induction of aortic IGF-I mRNA content after balloon denudation (7), indicating that local production of this growth factor may be a critical permissive factor for vascular SMC proliferation.

The purpose of the present study was to examine whether IGF-I accumulates in the vessel wall after balloon denudation and exerts its growth-promoting effects through interaction with specific IGF-I receptors. Furthermore, we examined the cellular source of IGF-I in the vessel wall, and the cells which may be the target of its action. We report that after balloon denudation of rat aorta, increased SMC IGF-I gene expression is associated with IGF-I receptor downregulation, and that these events take place with a reciprocal time course, supporting a role for local IGF-I gene expression and action in vascular tissue after injury.

\section{Methods}

Animals. Adult male Sprague-Dawley rats (400-500 g) were anesthetized with intraperitoneal pentobarbital. Balloon denudation of the aorta was performed with an inflated F2 Fogarty catheter, introduced through the right femoral artery and pulled with inflated balloon from the aortic arch into the abdominal aorta three times. The femoral artery was ligated after removal of the catheter. Aortae were harvested 1 , 7 , and $14 \mathrm{~d}$ after the intervention. For RNA extraction, radioimmunoassay of IGF-I and IGF-I binding studies the tissues were stripped of adventitia and immediately frozen in liquid nitrogen. For in situ hybridization studies, tissues were immersed in $4 \%$ paraformaldehyde and in $15 \%$ sucrose and after embedding in OCT frozen at $-70^{\circ} \mathrm{C}$.

IGF-I radioimmunoassay. IGF-I was immunoassayed by a heterologous equilibrium technique (8) using rabbit anti-hIGF-I polyclonal antibody (UBK487) distributed through the Hormone Distribution Program of National Institute of Diabetes and Digestive and Kidney Diseases, National Institutes of Health, of the National Hormone and Pituitary Program. This antiserum reacts with IGF-I of several species, including that of rat, and cross-reacts $<0.05 \%$ with hIGF-II. A final dilution of 1:16,000 of the anti-IGF-I antibody conferred $25-30 \%$ specific binding with [ ${ }^{125}$ I]IGF-I (Amersham Corp., Arlington Heights, IL). Recombinant [ Thr ${ }^{59}$ ]hIGF-I (Amgen Biologicals, Thousand Oaks, CA) was used for standards, with a minimal detectable dose of 2.0-3.0 pg. Serum was cleared by centrifugation and 1-ml aliquots acidified with $1 \mathrm{M}$ acetic acid for $60 \mathrm{~min}$, and filtered through an 
MPS-1 micropartition system (10,000-D cutoff; Amicon, Beverly, MA) to remove IGF-I binding proteins. Recovery of ${ }^{125}$ I-IGF-I was 85-93\%.

RNase protection assay. Total RNA was extracted from frozen tissues with guanidium thiocyanate using a commercially available kit (Cinna/Biotech Labs, Friendswood, TX). A modification of the method by Melton et al. (9) was used for RNase protection assay. Briefly, $40 \mu \mathrm{g}$ of tissue total RNA were resuspended in a hybridization buffer containing $20 \mathrm{mM}$ Tris $\mathrm{HCl}, \mathrm{pH} 7.6,1 \mathrm{mM}$ EDTA, $0.4 \mathrm{M} \mathrm{NaCl}$, $0.1 \%$ SDS, $75 \%$ deionized formamide, and $200,000 \mathrm{cpm}$ of labeled riboprobe. The mixture was heated to $85^{\circ} \mathrm{C}$ for $5 \mathrm{~min}$ and then incubated at $45^{\circ} \mathrm{C}$ for $16 \mathrm{~h} .40 \mu \mathrm{g} / \mathrm{ml} \mathrm{RNase} A$ and $2 \mu \mathrm{g} / \mathrm{ml} \mathrm{RNase} \mathrm{T1} \mathrm{were}$ then added for $1 \mathrm{~h}$ at $30^{\circ} \mathrm{C}$. The mixture was then incubated with SDS (final concentration $0.6 \%$ ) and $150 \mu \mathrm{g} / \mathrm{ml}$ proteinase $\mathrm{K}$ for $15 \mathrm{~min}$ at $37^{\circ} \mathrm{C}$, and then phenol/chloroform extracted. After addition of $20 \mu \mathrm{g}$ of tRNA, the RNA was precipitated in $2 \mathrm{vol}$ of ethanol at $-20^{\circ} \mathrm{C}$. Pellets containing the labeled RNA hybrids were resuspended in a gel loading buffer containing $80 \%$ deionized formamide, and size separated on an $8 \%$ polyacrylamide $/ 8 \mathrm{M}$ urea denaturing gel. After autoradiography, protected RNA bands were quantified by scanning densitometry.

In situ hybridization. 8- $\mu \mathrm{m}$ thick sections were mounted on sylilated glass slides and further fixed in 4\% paraformaldehyde. After immersion in $0.5 \times$ standard saline citrate (SSC) $(1 \times$ SSC equals $0.15 \mathrm{M}$ sodium chloride, $0.15 \mathrm{M}$ sodium citrate, $\mathrm{pH} 7.0$ ) and $5 \mu \mathrm{g} / \mathrm{ml}$ proteinase $\mathrm{K}$ solution, slides were prehybridized in a solution containing $50 \%$ formamide, $0.3 \mathrm{M} \mathrm{NaCl}, 20 \mathrm{mM}$ Tris- $\mathrm{HCl}, 5 \mathrm{mM}$ EDTA, $1 \times$ Denhardt's solution, $10 \%$ dextran sulfate, and $10 \mathrm{mM}$ DTT for $90 \mathrm{~min}$. Hybridization was performed with $2 \mu \mathrm{l}(300,000 \mathrm{cpm} / \mu \mathrm{l})$ of antisense riboprobe (see below) and $1 \mu \mathrm{l}$ of tRNA for $18-20 \mathrm{~h}$ at $50^{\circ} \mathrm{C}$. After the incubation, slides were washed at high stringency $\left(0.1 \times \mathrm{SSC}\right.$ at $52^{\circ} \mathrm{C}$ for $2 \mathrm{~h}$ ). Slides were then coated with nuclear emulsion and exposed in a light-tight box with desiccant. They were developed after 4 wk (10). For cell identification, slides were counterstained with hematoxylin/ eosin. Hybridization with liver tissue served as a positive control and hybridization on tissues pretreated with ribonuclease or hybridization with sense riboprobes (see below) served as negative controls.

Riboprobes. The probes used to detect the IGF-I and IGF-I receptor transcripts, kindly provided by Drs. C. Roberts, Jr., and D. LeRoith (National Institutes of Health), have been described elsewhere $(11,12)$. Briefly, the IGF-I cRNA construct contains a 322-bp complementary to the class A 5' untranslated region of IGF-I mRNA and protects 322 , 297, and 241 bases corresponding to class A, B, and C untranslated regions of IGF-I mRNA, respectively. IGF-I receptor mRNA was detected using a rat riboprobe 265 bases long, complementary to 15 bases of $5^{\prime}$ untranslated sequence and to a region encoding the signal peptide and the first 53 amino acids of the alpha subunit of the receptor.

For riboprobe generation the DNA template was transcribed with T7 (IGF-I) or SP6 polymerase (IGF-I receptor) and labeled in vitro with $\left[{ }^{32} \mathrm{P}\right]$ and ${ }^{35} \mathrm{~S}$-UTP for RNase protection assay and in situ hybridization experiments, respectively. Sense ${ }^{35} \mathrm{~S}$-riboprobe used for negative control in the in situ hybridization studies were reciprocally transcribed with SP6 (IGF-I) and T7 polymerase (IGF-I receptor), respectively.

IGF-I binding assay on SMC crude membranes. Crude membranes were prepared from pooled aortae $(n=10)$ obtained from control rats and from rats $7 \mathrm{~d}$ after denudation according to the method of Havrankova (13). The tissues were washed in cold saline, and homogenized in an ice cold solution containing $1 \mathrm{mM} \mathrm{NaHCO}, 10 \mu \mathrm{g} / \mathrm{ml}$ leupeptin, 1 trypsin inhibitor unit/ml aprotinin, and $2 \mathrm{mM}$ PMSF in a blender (Polytron; Brinkman Instruments Co., Westbury, NY) and the homogenates centrifuged at $600 \mathrm{~g}$. The supernatant was further centrifuged at $20,000 \mathrm{~g}$, and the final pellets resuspended in $\mathrm{Ca}^{++}$-free $\mathrm{KRB}$. Protein concentration was determined according to the method of Lowry (14). ${ }^{125}$ I-IGF-I binding was determined as described by Lowe et al. (15). 50 $\mu \mathrm{l}$ of $\mathrm{Ca}^{++}$-free $\mathrm{KRB} / 0.1 \%$ BSA with or without various concentrations of unlabeled IGF-I were added to $50 \mu \mathrm{l} \mathrm{Ca}{ }^{++}$-free $\mathrm{KRB}$ with $3 \%$ BSA, $3 \mathrm{mg} / \mathrm{ml}$ bacitracin, and $\sim 0.15 \mathrm{ng} / \mathrm{ml}^{125} \mathrm{I}-\mathrm{IGF}-\mathrm{I}(15,000 \mathrm{cpm})$.
$50 \mu \mathrm{l}$ of membrane suspension containing $\sim 200 \mu \mathrm{g}$ of protein was then added, and the mixture incubated for $18 \mathrm{~h}$ at $\sim 4^{\circ} \mathrm{C}$. Membranebound and free ${ }^{125}$ I-IGF-I were separated by centrifugation, and the excised tips with the pellets washed, and the radioactivity determined in a gamma counter. Nonspecific binding was defined as counts of ${ }^{125}$ I-IGF-I remaining associated with membranes in the presence of 500 $\mathrm{ng} / \mathrm{ml}$ of unlabeled IGF-I, and were subtracted from total binding to yield the specific binding. To determine whether the differences in binding were due to changes in receptor affinity or number, competition/ inhibition experiments were performed and data plotted according to the method of Scatchard (16).

Statistical analysis. The significance of differences was determined using analysis of variance.

\section{Results}

Total IGF-I mRNA content in the aortae from rats before, 1, 7, and $14 \mathrm{~d}$ after denudation was determined using a solution hybridization/RNase protection assay (Fig. 1). Consistent with our previous report only class $C 5^{\prime}$ untranslated mRNA was present in aortic tissue and its content increased severalfold after denudation. Liver is the major source of circulating IGF-I levels (4). The expression of IGF-I mRNA in the liver was not affected by the aortic denudation (data not shown), indicating that activation of aortic IGF-I gene expression occurs in response to local, and not systemic, stimuli.

Fig. 2, $a$ and $b$, shows examples of in situ hybridization in the normal and denuded aortae. In the control rats, hybridization with antisense IGF-I riboprobe localized IGF-I mRNA to medial SMCs. The distribution was fairly uniform among those cells. IGF-I transcripts were present to a lesser extent in the adventitial but not in the endothelial layer. In situ hybridization after denudation also localized IGF-I transcripts to medial SMCs. The intensity of hybridization was markedly increased throughout medial SMCs at $7 \mathrm{~d}$. IGF-I mRNA transcripts were also present in the mesenchymal cells of the neointima. There was marked hybridization of the antisense IGF-I riboprobe to hepatocytes ( Fig. $2 c$ ), used as positive controls for each hybridization experiment. Sense strand IGF-I riboprobe did not hybridize to liver or aortic tissue sections (data not shown).

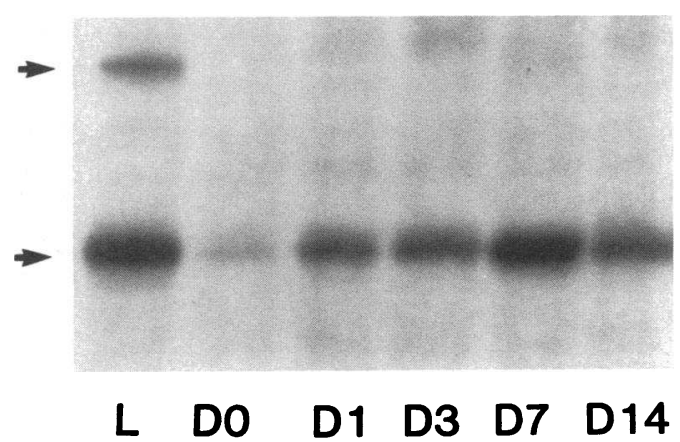

Figure 1. Regulation of IGF-I mRNA transcripts in the aorta after balloon denudation. A solution hybridization/RNase protection assay using an IGF-I riboprobe complementary to class A 5' untranslated IGF-I mRNA is shown. $40 \mu \mathrm{g}$ of total RNA from normal rat liver $(L)$ and aortae pooled from four rats before $(D O), 1 \mathrm{~d}(D I), 3$ $\mathrm{d}(D 3), 7 \mathrm{~d}(D 7)$, and $14 \mathrm{~d}(D 14)$ after denudation were hybridized with the riboprobe as described in Methods. Liver contained both class A and class $\mathrm{C} 5^{\prime}$ (arrows) untranslated IGF-I mRNA transcripts. Aortae contained solely class C IGF-I mRNA. 

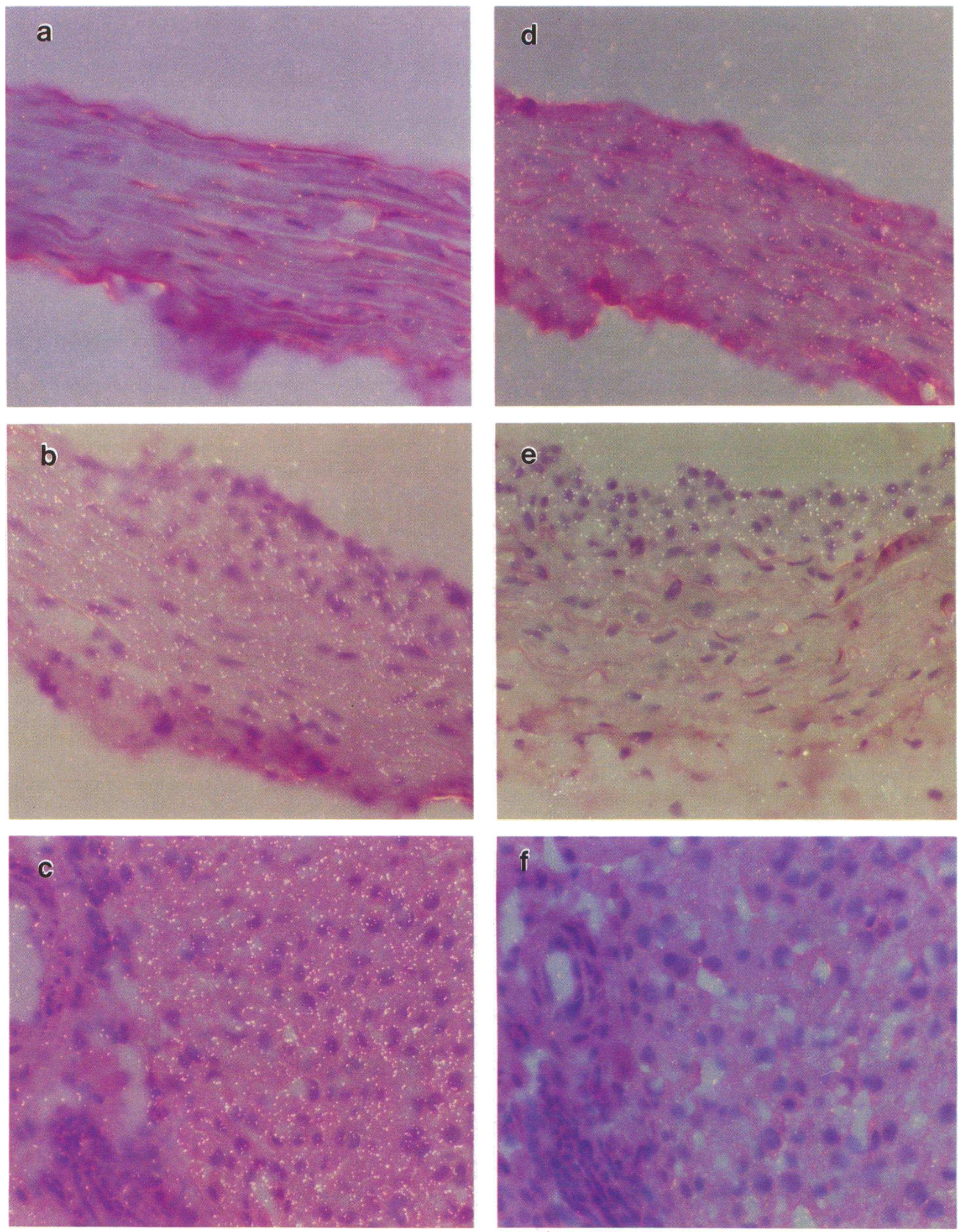

Figure 2. Localization of IGF-I and IGF-I receptor mRNA in rat aorta after injury. Sections were hybridized with ${ }^{35}$ S-labeled antisense probe and exposed for $4 \mathrm{wk}$. Sections $(a)$ normal aorta, $(b)$ aorta $7 \mathrm{~d}$ after denudation with neointimal proliferation, and $(c)$ liver, were hybridized with IGF-I riboprobe. Sections $(d)$ normal aorta, $(e)$ aorta $7 \mathrm{~d}$ after denudation with neointimal proliferation, and $(f)$ liver, were hybridized with IGF-I receptor probe. (All panels dark-field microscopy, $\times 20$ ). 
The time course of tissue concentration of radioimmunoassayable IGF-I in the aorta after denudation is shown in Fig. 3. Tissue immunoassayable IGF-I increased from $\sim 25 \mathrm{ng} / \mathrm{g}$ in control aortic tissue to a maximum of $72 \mathrm{ng} / \mathrm{g} 7 \mathrm{~d}$ after denudation. Serum IGF-I levels did not change at any time after denudation (data not shown).

The biological effects of IGF-I are mediated through interaction with its specific receptor and are dependent in part on ligand and receptor gene expression, and translocation of the receptor to the plasma membrane. Aortic tissue IGF-I receptor mRNA content was determined using a solution hybridization/RNase protection assay (Fig. 4). Aortic IGF-I receptor mRNA content decreased to $71 \pm 10 \%$ of control in aortae harvested $7 \mathrm{~d}$ after denudation. In liver the expression of IGF-I receptor mRNA was minimal, consistent with previous data that the IGF-I receptor is not present in hepatocytes (15).

Fig. 2, $d$ and $e$, shows examples of in situ hybridization with the antisense IGF-I receptor riboprobe in the normal and denuded rat aortae $7 \mathrm{~d}$ after denudation. The IGF-I receptor riboprobe hybridized to medial SMC in the normal aortae. At $7 \mathrm{~d}$ after denudation, when neointimal proliferation was present, the hybridization was predominantly to the neointimal SMC. At all time points studied there were also adventitial cells containing IGF-I receptor mRNA transcripts. There was no appreciable hybridization of antisense IGF-I receptor riboprobe with liver (Fig. $2 f$ ). Sense strand riboprobe (negative control) failed to hybridize to the aortic tissue sections (data not shown).

We examined whether the decreased expression of IGF-I receptor mRNA at $7 \mathrm{~d}$ also resulted in changes in IGF-I binding to crude membrane preparation of aortic tissue. After injury, there was an $\sim 40 \%$ decrease of specific ${ }^{125}$ I-IGF-I binding to aortic membranes. To determine whether this decrease in ${ }^{125}$ I-IGF-I binding was due to changes in receptor affinity or number, competition/inhibition experiments were conducted (Fig. 5). When the data were plotted according to the method of Scatchard, a straight line was obtained, indicating the presence of a single class of binding sites. There was no change in receptor affinity $\left(K_{\mathrm{d}}: 3.88 \mathrm{nM}\right.$ and $3.34 \mathrm{nM}$, control and $7 \mathrm{~d}$ after denudation, respectively). There was, however a marked decrease in receptor number in the injured vessels $7 \mathrm{~d}$ after denudation (receptor concentration $\left[R_{0}\right]=0.137 \mathrm{pmol} / \mathrm{ml}$

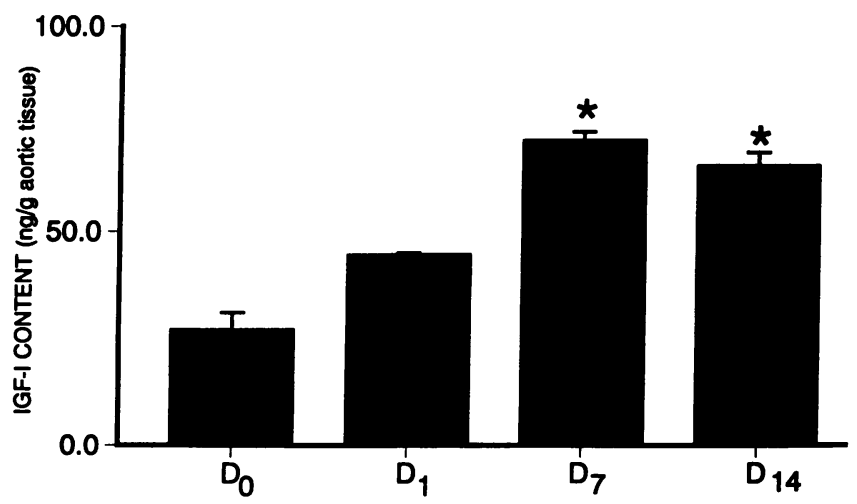

Figure 3. IGF-I content in aortic tissue extracts. Radioimmunoassayable IGF-I was determined before $(D 0)$, and $1 \mathrm{~d}(D 1), 7 \mathrm{~d}(D 7)$, and $14 \mathrm{~d}(D 14)$ after denudation. Each value represents the mean from two separate determinations. ${ }^{*} P<0.05$ compared to $\mathrm{D} 0$.

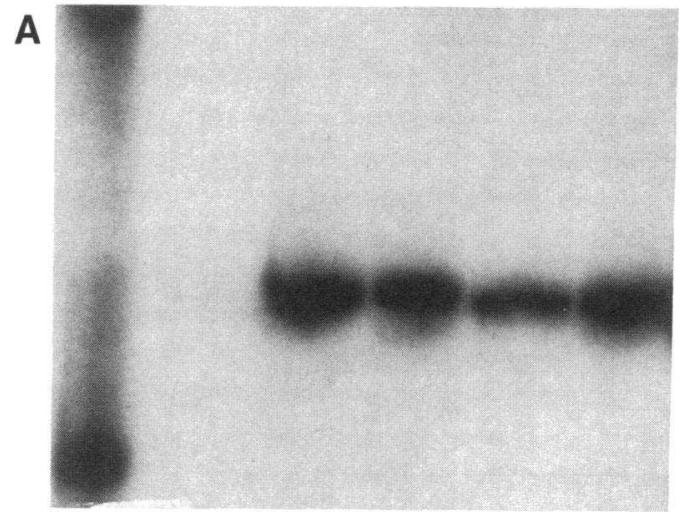

M L DO D1 D7 D14

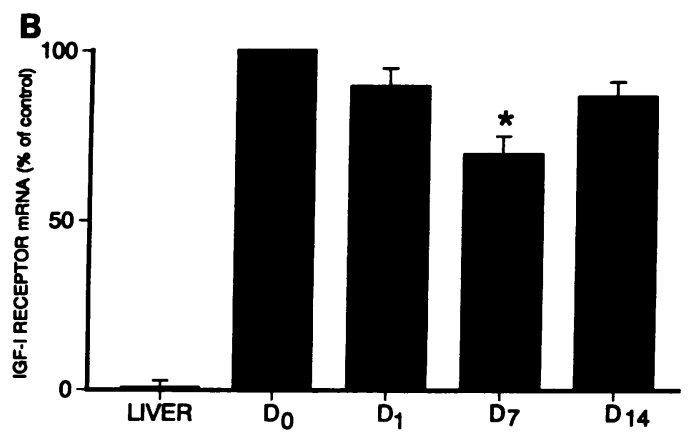

Figure 4. (A) Regulation of IGF-I receptor mRNA in rat aorta after balloon denudation. A solution hybridization/RNase protection assay using a 265 base rat IGF-I receptor riboprobe complementary to 15 bases of 5 ' untranslated sequence and a region encoding the signal peptide and the first 53 amino acids of the alpha subunit. $40 \mu \mathrm{g}$ of total RNA from normal rat liver $(L)$, aortae pooled from four rats before $(D 0), 1 \mathrm{~d}(D 1), 7 \mathrm{~d}(D 7)$, and $14 \mathrm{~d}(D 14)$ after balloon denudation were hybridized with the riboprobe as described in Methods. ${ }^{32} \mathrm{P}$-end-labeled molecular weight markers of 370 and 227 bases $(M)$ are also shown. $(B)$ Quantification of aortic IGF-I receptor mRNA content after balloon denudation. Densitometric intensity from five separate experiments relative to levels of protected fragments in normal aortae is shown. ${ }^{*} P<0.025$ compared to $\mathrm{D} 0$.

per $200 \mu \mathrm{g}$ protein $)$ as compared to control $\left(\mathrm{R}_{0}=0.422 \mathrm{pmol} /\right.$ $\mathrm{ml}$ per $200 \mu \mathrm{g}$ protein).

\section{Discussion}

In this study we show that after balloon denudation, induction of aortic IGF-I gene expression is associated with downregulation of its receptor. This suggests that IGF-I may act in a paracrine fashion in the process of vascular repair after balloon injury.

Indeed, there is growing evidence that SMC proliferation at the site of arterial injury might be modulated in part by a number of locally produced growth factors, such as PDGF-A chain (3) and fibroblast growth factor (17). As IGF-I functions as a progression factor for mitogen-induced vascular SMC growth, we and others have suggested that local IGF-I production may also be involved in the process of healing of the injured arterial wall $(7,18)$. For locally produced IGF-I to play a role in this process, it is important to show that the IGF-I mRNA tran- 


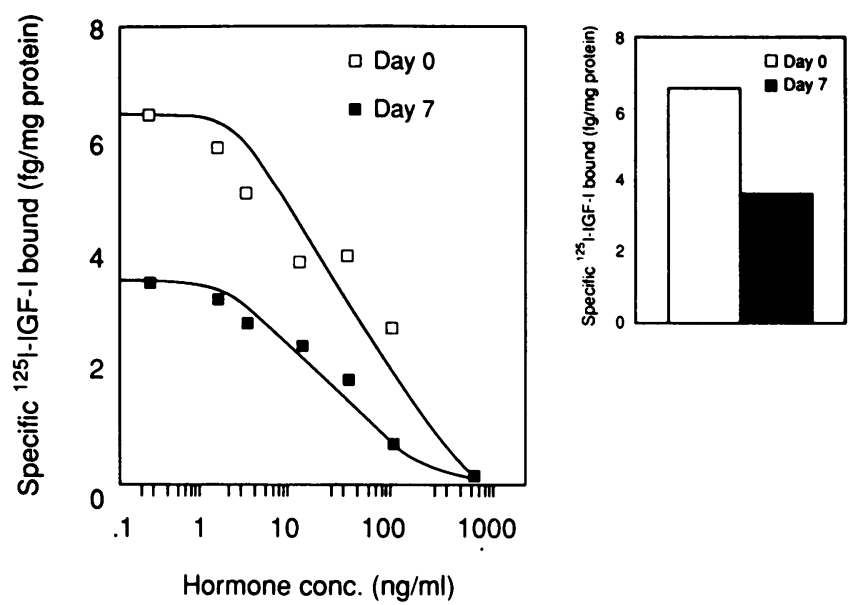

Figure 5. IGF-I binding to aortic membranes. Competition/inhibition of IGF-I binding to preparations of crude membranes of normal rat aortae (day 0 , open squares) and aortae $7 \mathrm{~d}$ after balloon denudation (day 7, closed squares). Membranes were incubated with ${ }^{125} \mathrm{I}$ IGF-I and increasing concentrations of unlabeled IGF-I as described in Methods. Specific binding of ${ }^{125} \mathrm{I}-\mathrm{IGF}-\mathrm{I} / \mathrm{mg}$ membrane protein was plotted against unlabeled IGF-I concentration. (Inset) Specific ${ }^{125}$ I-IGF-I binding before (day 0, open bar) and $7 \mathrm{~d}$ after denudation (day 7, closed bar).

scripts are actually translated, to identify the cells that produce it, and to determine that it exerts its effects through its specific receptor.

Consistent with our initial observation (7), we have found increased aortic IGF-I mRNA content as soon as $1 \mathrm{~d}$ after denudation, increasing to about ninefold control levels $7 \mathrm{~d}$ after denudation. The predominant site of IGF-I gene expression in both normal and denuded vessel wall was the medial SMC. Previously reported studies suggested that endothelial cells express predominantly IGF-II (19), but also some IGF-I mRNA (20). In our in vivo study normal endothelial cells were not an important source of IGF-I transcripts. The localization of IGF-I mRNA to medial SMC appears to be inconsistent with a previous report in which IGF-I immunoreactivity after balloon denudation was observed mainly in the luminal area of the vessel (21). We also observed a similar staining pattern using a polyclonal antibody to human IGF-I (data not shown). Immunohistochemistry of IGF-I has a major technical caveat which hampers interpretation of these data. Vascular SMC abundantly express insulin-like growth factor binding proteins and the expression of some of these is regulated by PDGF (22). IGF binding proteins have high affinity for IGF-I and very markedly interfere with the interaction between IGF-I and its antibody, thus may explain spurious localization patterns. We cannot, however, fully exclude that IGF-I mRNA expressed by medial SMC was not efficiently translated, or that IGF-I was rapidly degraded or shunted to the neointimal compartment.

In spite of the inability to effectively use immunohistochemistry to demonstrate IGF-I in the blood vessel, in this report we provide evidence that the increase in aortic IGF-I mRNA after denudation was paralleled by an increase in radioimmunoassayable IGF-I in the aortic wall. In this case, IGF-I was measured after removing all trace of IGF binding proteins from the tissue extracts. The tissue content of IGF-I ligand was again highest at $7 \mathrm{~d}$ after denudation. This makes it unlikely that the increase in aortic IGF-I content would result from tissue infil- tration by plasma, in which case a rapid increase after injury would have been observed.

Balloon denudation also induced alterations of IGF-I receptor mRNA expression and of IGF-I binding. A $25 \%$ decrease in IGF-I receptor mRNA content was observed $7 \mathrm{~d}$ after denudation. Specific binding to aortic membranes of control rats was comparable to that observed in heart tissue (15). The significant decrease of $\sim 40 \%$ in IGF-I binding to membranes from injured aortae $7 \mathrm{~d}$ after denudation, a time when immunoassayable IGF-I concentration was at its highest, provides indirect evidence for IGF-I action in these tissues. Scatchard analysis of the binding studies indicated a single class of binding sites, as reported for IGF-I by others (23). There was a marked decrease in receptor number in the injured vessels with no change in receptor activity. In the uninjured vessel, IGF-I receptor mRNA localized to medial smooth muscle cells and adventitial tissue. After denudation there was a relative decrease in IGF-I receptor mRNA in the medial cells as compared to the neointima, suggesting that the site of IGF-I action was predominantly in the medial layer. We cannot exclude that IGF-I receptor expression may have been downregulated by other factors, independent of IGF-I action. These data, however, are compatible with recent observation of coordinate changes in tissue IGF-I receptor mRNA content and IGF-I binding in conditions such as fasting (15).

Several investigators have reported a gradient of SMC proliferation from lumen to adventitia after balloon injury (24). PDGF is expressed by cells adjacent to the intima (3), suggesting that this growth factor may be prominent in the initial SMC proliferative response after injury. In contrast, the predominant localization of IGF-I production and action to the arterial media raises the possibility that IGF-I may have a permissive effect on SMC growth promotion. It is also likely that IGF-I may have other biological effects besides promoting SMC proliferation. Foster et al. have observed that IGF-I induces the synthesis of tropoelastin in aortic tissues (25). As the media is stretched and often damaged by balloon inflation, it is reasonable to assume that local production of IGF-I may play a role in regenerating the elastic layer.

The factors that regulate vessel wall IGF-I gene expression have not been determined. Growth hormone is a well established endocrine regulator of IGF-I gene expression, predominantly in liver (4). In our study denudation did not appreciably change liver IGF-I mRNA content nor plasma IGF-I levels. In addition, our studies in hypophysectomized rats have shown that while basal IGF-I mRNA content in the rat aorta is decreased, the relative increase after denudation is well preserved (26). These findings suggest that other factors, most likely local, regulate IGF-I gene expression in the vessel wall in response to injury. These factors have yet to be determined. One possible candidate is PDGF, shown to be capable of IGF-I induction in cultured mesenchymal cells (27). PDGF could potentially arise from adhering platelets or, more likely, from local expression by SMC or regenerating endothelium $(28,29)$. The significance of the potential synergism between PDGF and IGF-I in vascular repair is highlighted by studies in porcine skin wounds (30). The combination of PDGF and IGF-I was the most effective stimulator of healing compared to other individual factors and their combinations.

The association of neointimal proliferation with local PDGF and IGF-I gene expression suggests that a combination of locally and blood-borne growth factors regulate vascular re- 
sponse to injury, and that these are acting at specific times and within discrete compartments of the vessel wall.

\section{Acknowledgments}

The authors greatly appreciate the excellent technical support of Paul Dimayuga and Amin Kamyar and are grateful to Drs. Derek LeRoith and Charles Roberts for providing the IGF-I and IGF-I receptor probes. The authors also thankfully acknowledge the expert suggestions of Dr. Josiah Wilcox with the in situ hybridization studies and Dr. Michael Fishbein with photomicroscopy.

The research presented in this publication was supported by Medallion Foundation and Grand Sweepstakes Foundation.

\section{References}

1. Clowes, A. W., M. A. Reidy, and M. M. Clowes. 1983. Mechanisms of stenosis after arterial injury. Lab. Invest. 49:208-215.

2. Ross, R. 1986. The pathogenesis of atherosclerosis: an update. N. Engl. J. Med. 4:488-500.

3. Majesky, M. W., M. A. Reidy, D. F. Bowen-Pope, C. E. Hart, J. N. Wilcox, and S. M. Schwartz. 1990. PDGF ligand and receptor gene expression during repair of arterial injury. J. Cell Biol. 111:2149-2158.

4. Sara, V. R., and K. Hall. 1990. Insulin-like growth factors and their binding proteins. Physiol. Rev. 70:591-614.

5. Clemmons, D. R., and J. J. Van Wyk. 1985. Evidence for a functional role of endogenously produced somatomedin-like peptides in the regulation of DNA synthesis in cultured human fibroblasts and porcine smooth muscle cells. J. Clin. Invest. 75:1914-1918.

6. Pardee, A. B. 1990. G1 events and regulation of cell proliferation. Science (Wash. DC). 246:603-608.

7. Cercek, B., M. C. Fishbein, J. S. Forrester, R. H. Helfant, and J. A. Fagin. 1990. Induction of insulin-like growth factor-I messenger RNA in rat aorta after balloon denudation. Circ. Res. 66:1755-1760.

8. Daughaday, W. H., I. K. Mariz, and S. L. Blethen. 1980. Inhibition of access of bound somatomedin to membrane receptor and immunobinding sites: a comparison of radioreceptor and radioimmunoassay of somatomedin in native and acid-ethanol-extracted serum. J. Clin. Endocrinol. \& Metabol. 51:781-788.

9. Melton, D. A., P. A. Krieg, M. R. Rebagliati, T. Maniatis, K. Zinn, and M. R. Green. 1984. Efficient in vitro synthesis of biologically active RNA and RNA hybridization probes from plasmids containing a bacteriophage SP6 promoter. Nucleic Acids Res. 12:7035-7056.

10. Wilcox, J. N., K. M. Smith, L. T. Williams, S. M. Schwartz, and D. Gordon. 1988. Platelet-derived growth factor mRNA detection in human atherosclerotic plaques by in situ hybridization. J. Clin. Invest. 82:1134-1143.

11. Roberts, C. T., S. R. Lasky, W. L. Lowe, W. T. Seaman, and D. LeRoith 1987. Molecular cloning of rat insulin-like growth factor-I complementary deoxyribonucleic acids: differential messenger ribonucleic acid processing and regulation by growth hormone in extrahepatic tissues. Mol. Endocrinol. 1:243-248.
12. Wermer, H. M., M. Woloschak, M. Adamo, Z. Shen-Orr, C. T. Roberts, and D. LeRoith. 1989. Developmental regulation of the rat insulin-like growth factor I receptor gene. Proc. Natl. Acad. Sci. USA. 86:7451-7455.

13. Havrankova, J., J. Roth, and M. Brownstein. 1977. Insulin receptors are widely distributed in the central nervous system of the rat. Nature (Lond.). 272:827-829.

14. Lowry, O. H., N. J. Rosebrough, A. L. Farr, and R. J. Randall. 1951. Protein measurement with Folin phenol reagent. J. Biol. Chem. 193:265-268.

15. Lowe, W. L., Jr., M. Adamo, H. Wermer, C. T. Roberts, Jr., and D. LeRoith. 1989. Regulation by fasting of rat insulin-like growth factor-I and its receptor. J. Clin. Invest. 84:619-626.

16. Scatchard, G. 1949. The attractions of proteins for small molecules and ions. Ann. NY Acad. Sci. 51:660-672.

17. Lindner, V., D. A. Lappi, A. Baird, R. A. Majack, and M. A. Reidy. 1991. Role of basic fibroblast growth factor in vascular lesion formation. Circ. Res. 68:106-113.

18. Hansson, H. A., E. Jennische, and A. Skottner. 1987. IGF-I expression in blood vessels varies with vascular blood load. Acta Physiol. Scand. 129:165-169.

19. Kern, P. A., M. E. Svoboda, D. Graves, R. H. Eckel, and J. J. Van Wyk. 1989. Insulin-like growth factor action and production in adipocytes and endothelial cells from human adipose tissue. Diabetes. 38:710-717.

20. Delafontaine, P., K. Bernstein, and R. W. Alexander. 1989. Cultured endothelial cells produce insulin-like growth factor I. Circulation. 80:II-6. (Abstr.).

21. Hansson, H.-A., E. Jennische, and A. Skottner. 1987. Regenerating endothelial cells express insulin-like growth factor-I immunoreactivity after arterial injury. Cell Tissue Res. 250:499-505.

22. Giannella-Neto, D., A. Kamyar, J. S. Forrester, and J. A. Fagin. 1990 Platelet derived growth factor isoforms induce insulin-like growth factor gene expression and the production of its binding protein in rat smooth muscle cells. Circulation. 82(Suppl. III):III-209. (Abstr.).

23. Tollefsen, S. E., and K. Thompson. 1988. The structural basis for insulinlike growth factor I receptor high affinity binding. J. Biol. Chem. 263:1626716273.

24. Clowes, A. W., M. M. Clowes and M. A. Reidy. 1986. Kinetics of cellular proliferation after arterial injury. Lab. Invest. 54:295-303.

25. Foster, J., C. B. Rich, and J. R. Florini. 1987. Insulin-like growth factor I, somatomedin $\mathrm{C}$, induces the synthesis of tropoelastin in aortic tissue. Collagen Relat. Res. 7:161-169.

26. Khorsandi, M. J., J. A. Fagin, M. C. Fishbein, J. S. Forrester, and B Cercek. 1992. Effects of hypophysectomy on vascular insulin-like growth factor I gene expression after balloon denudation in rats. Atherosclerosis. 93:115-122.

27. Ross, R., E. W. Raines, and D. F. Bowen-Pope. 1986. The biology of platelet derived growth factor. Cell. 46:155-169.

28. Fingerle, J., R. Johnson, A. W. Clowes, M. W. Majesky, and M. A. Reidy. 1989. Role of platelets in smooth muscle cell proliferation and migration after vascular injury in rat carotid artery. Proc. Natl. Acad. Sci. USA. 86:8412-8416.

29. Golden, M. A., Y. P. Tina Au, T. R. Kirkman, J. N. Wilcox, E. W. Raines, R. Ross, and A. W. Clowes. 1991. Platelet-derived growth factor activity and mRNA expression in healing vascular grafts in baboons. J. Clin. Invest. 87:406414

30. Lynch, S. E., R. B. Colvin, and H. N. Antoniades. 1989. Growth factors in wound healing. J. Clin. Invest. 84:640-646. 